www.nature.com/pj

\title{
Synthesis and photovoltaic properties of two-dimensional conjugated polymers with tunable pendant acceptor groups
}

\author{
Lingyan Liao ${ }^{1,2}$, Wei Zhang ${ }^{2}$, Zuo Xiao ${ }^{2}$, Jiamin $\mathrm{Cao}^{2}$, Zhanpeng Liu ${ }^{1}$, Qiqun Zuo ${ }^{3}$ and Liming Ding ${ }^{2}$
}

Polymer Journal (2013) 45, 571-575; doi:10.1038/pj.2012.172; published online 26 September 2012

Keywords: benzo[1,2-b:4,5-b']dithiophene; conjugated polymers; low-lying HOMO levels; pendant acceptor groups; polymer solar cells

\section{INTRODUCTION}

Polymer bulk heterojunction solar cells (PSCs), based on an electrondonating conjugated polymer and an electron-accepting fullerene derivative, ${ }^{1-2}$ have attracted considerable attention over the past decade due to their unique advantages of low cost, light weight and feasible roll-to-roll fabrication for making flexible large-area devices. $^{1-3}$ Intensive research efforts have focused on improving the power conversion efficiency (PCE) of PSCs. There are several factors limiting the PCE of PSCs: first, limited light absorption of the photoactive layer leads to low short-circuit current; second, small energy level difference between HOMO of the polymer donors and LUMO of the acceptors limits the open-circuit voltage $\left(V_{\mathrm{oc}}\right){ }^{4-7}$ Therefore, development of conjugated polymers with low bandgaps for efficient solar energy absorption and deep HOMO levels for high $V_{\text {oc }}$ are expected for highly efficient PSCs. ${ }^{8-9}$ An efficient strategy is to synthesize two-dimensional conjugated polymers. ${ }^{10-12}$ These polymers feature high hole mobility because of extended conjugation, and broad absorption contributed by both main chain and side chains, thus demonstrating remarkable photovoltaic properties. ${ }^{13-15}$ In this work, we designed a series of two-dimensional conjugated polymers (P1-P4) based on a benzo [1,2-b:4,5- $\left.\mathrm{b}^{\prime}\right]$ dithiophene (BDT) unit and a thiophene unit with a pendant acceptor group. BDT is a highly coplanar electron-donating moiety, which could improve the inter-chain $\pi-\pi$ stacking of conjugated polymers. Polymers based on BDT exhibit high performance in PSCs. ${ }^{16-18}$ A thiophene unit with tunable pendant electron-deficient groups is used to efficiently tune the energy levels of the copolymers to achieve better optical properties for the polymers and high $V_{\mathrm{oc}}$ for the devices.

\section{RESULTS AND DISCUSSION}

The synthetic routes for monomers (M1-M4) are shown in Figure 1. M1-M4 were synthesized in moderate or good yields through reactions including Friedel-Crafts acylation, Suzuki coupling, Knoevenagel condensation and bromination. Detailed synthetic procedures and yields of the products are presented in the Supplementary Information. M1 consists of a 2, 3'-bithiophene moiety. To enhance the solubility and electron-withdrawing property, we introduced a 2-ethylhexanoyl group at the C5 position of M1. We further designed monomers M2-M4 by modifying M1. For M2, a cyanovinylene bridge is introduced between the two thiophenes of M1. This modification can effectively extend the conjugation and further enhance the electron-withdrawing property of the unit. For the same purpose, a phenylene and a 2-fluorophenylene group are introduced between the thiophene and cyanovinylene for M3 and M4, respectively. The donor monomer M5 was prepared according to the literature. ${ }^{18,19}$ As shown in Figure 2, polymers (P1-P4) were prepared through a Stille coupling reaction between the donor monomer M5 and the acceptor monomers (M1-M4). The crude products were precipitated in methanol, then purified by Soxhlet extraction using methanol, hexane and chloroform successively. The chloroform fraction was precipitated in methanol, filtered and dried under vacuum to obtain P1-P4. The chemical structures of P1-P4 were verified by ${ }^{1} \mathrm{H}$ NMR. All polymers exhibited good solubility in common organic solvents, such as THF, $\mathrm{CHCl}_{3}$ and chlorobenzene. The molecular weights of polymers (P1-P4) were determined by GPC and are listed in Supplementary Table S1. $M_{\mathrm{n}}$ of P1-P4 are 20.8, 27.8, 19.6 and $17.0 \mathrm{~kg} \mathrm{~mol}^{-1}$, respectively.

\footnotetext{
${ }^{1}$ College of Chemistry, Key Laboratory of Environment-Friendly Chemistry and Applications of Ministry of Education, Xiangtan University, Xiangtan, China; ${ }^{2}$ National Center for Nanoscience and Technology, Beijing, China and ${ }^{3}$ Jiahong Optoelectronics, Suzhou, China

Correspondence: Dr Z Liu, College of Chemistry, Key Laboratory of Environment-Friendly Chemistry and Applications of Ministry of Education, Xiangtan University, Xiangtan 411105, China.

E-mail: zpliu@xtu.edu.cn

or Dr L Ding, National Center for Nanoscience and Technology, Beijing 100190, China.

E-mail: OPV.CHINA@yahoo.com
}

Received 19 April 2012; revised 3 July 2012; accepted 4 July 2012; published online 26 September 2012 
<smiles>CCCCC(CC)C(=O)Cl</smiles>

1

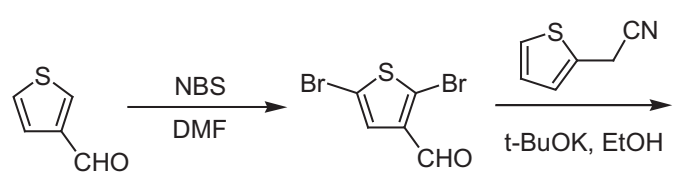

3<smiles>O=Cc1ccc(Br)cc1</smiles><smiles>CC(C)(C)OCCCCc1cccs1</smiles><smiles>Brc1cc(-c2ccccc2)c(Br)s1</smiles><smiles>CC/C=C(/C=[V])c1cccs1</smiles><smiles>N#C/C(=C\c1cc(Br)sc1Br)c1cccs1</smiles>

4<smiles>O=Cc1ccc(-c2ccsc2)cc1</smiles><smiles>CCCCC(CC)C(=O)Cl</smiles><smiles>CO[Nb]</smiles><smiles>Brc1cccs1</smiles><smiles>c1ccc2c(c1)CSC2</smiles><smiles>O=Cc1ccc(-c2cc(Br)sc2Br)cc1</smiles>

M2

M1<smiles>CCCCC(CC)C(=O)c1ccc(C(C#N)=Cc2cc(Br)sc2Br)s1</smiles>

6<smiles>CCCCC(CC)C(=O)c1ccc(C(C#N)=Cc2ccccc2)s1</smiles><smiles>O=Cc1ccc(Br)cc1F</smiles><smiles>Oc1ccsc1</smiles>

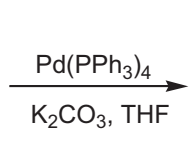<smiles>O=Cc1ccc(-c2ccsc2)cc1F</smiles><smiles>[Nb][SnH3]</smiles><smiles>O=Cc1ccc(-c2cc(Br)sc2Br)cc1F</smiles><smiles>C=CCCC(CC)C(=O)c1ccc(/C(C#N)=C/c2ccc(-c3cc(Br)sc3Br)cc2F)s1</smiles>

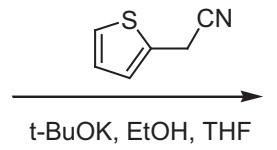<smiles>N#C/C(=C\c1ccc(-c2cc(Br)sc2Br)cc1F)c1cccs1</smiles><smiles>CCCCC(CC)C(=O)Cl</smiles>

Figure 1 Synthesis of monomers.

The thermal stabilities of the polymers were evaluated by TGA under $\mathrm{N}_{2}$. As shown in Supplementary Figure S1, polymers P1-P4 exhibit good thermal stability with decomposition temperatures at $325,333,283$ and $325^{\circ} \mathrm{C}$, respectively, indicating that all polymers are thermally stable for solar cell applications.

Figure 3 shows the absorption spectra of the copolymers in solution and in films and the data are summarized in Table 1.
P2, P3 and P4 show similar absorption spectra. In solution, the absorption maxima are located at $389 \mathrm{~nm}$ for P2, $386 \mathrm{~nm}$ for P3 and $385 \mathrm{~nm}$ for P4 (Figure 3a), corresponding to the $\pi-\pi^{\star}$ transition of the polymer backbone. Additionally, P2, P3 and P4 spectra all show a shoulder at longer wavelengths, which can be attributed to intramolecular charge transfer (ICT) between conjugated backbones and respective pendant acceptor groups. ${ }^{10} \mathbf{P 1}$ shows an absorption 

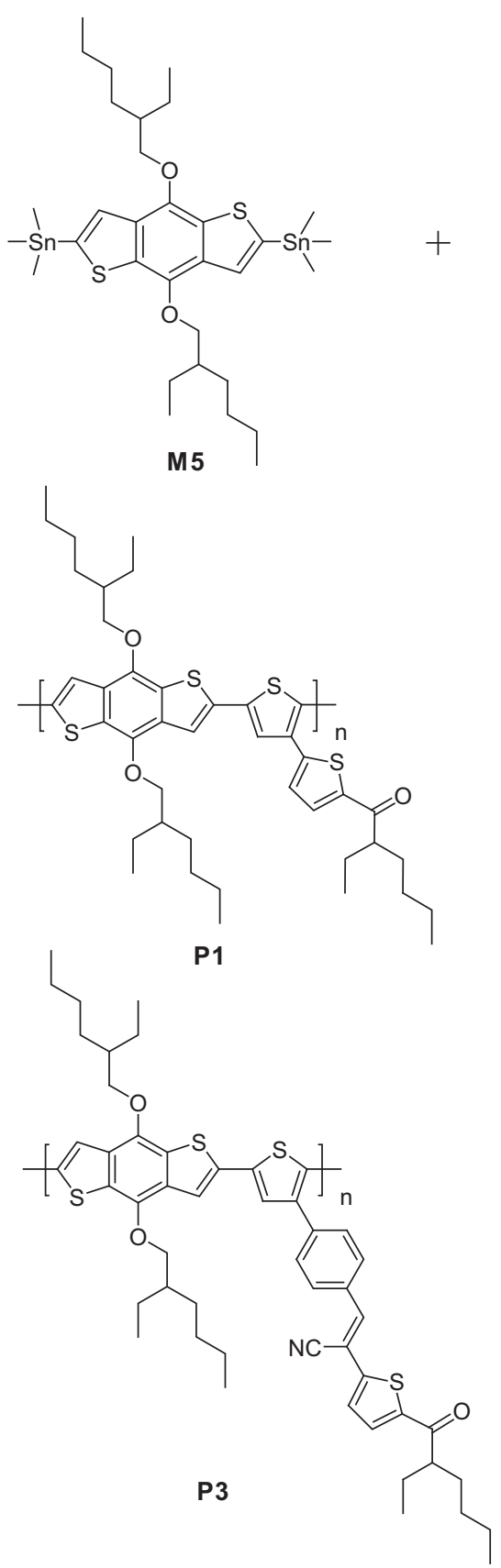

Figure 2 Synthesis of polymers.

maximum at $474 \mathrm{~nm}$, which might be due to the stronger ICT effect. In films, the intensity of the ICT bands for all polymers is significantly enhanced, indicating the improvement of interchain interactions in the solid state (Figure 3b). P2 shows the broadest absorption $(300 \sim 700 \mathrm{~nm})$, suggesting the potential for high photocurrent. The optical bandgaps $\left(E_{\mathrm{g}}{ }^{\mathrm{opt}}\right)$ of the polymers are 2.05, 1.86, 2.04 and $2.01 \mathrm{eV}$, respectively, which were calculated from the film absorption onsets.

Cyclic voltammograms of the polymers P1-P4 are shown in Supplementary Figure S2. The onset oxidation and reduction potentials of the polymers are listed in Table 1. The HOMO and LUMO energy levels and electrochemical bandgaps $\left(E_{\mathrm{g}}{ }^{\mathrm{ec}}\right)$ of polymers

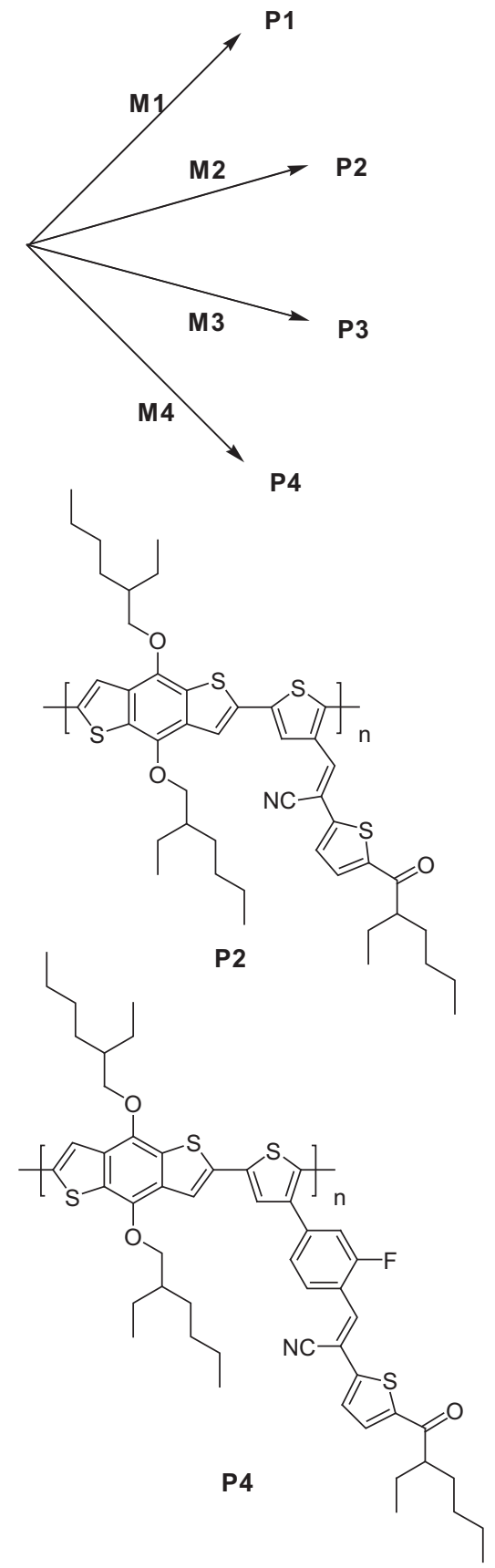

were calculated according to the following empirical equations: ${ }^{20}$

$$
\begin{aligned}
E_{\mathrm{HOMO}} & =-\mathrm{e}\left(E_{\mathrm{ox}}^{\mathrm{on}}+4.8\right)(\mathrm{eV}) \\
E_{\mathrm{LUMO}} & =-\mathrm{e}\left(E_{\mathrm{red}}^{\mathrm{on}}+4.8\right)(\mathrm{eV}) \\
E_{\mathrm{g}}^{\mathrm{ec}} & =E_{\mathrm{LUMO}}-E_{\mathrm{HOMO}}(\mathrm{eV})
\end{aligned}
$$

As shown in Table 1, P1-P4 exhibit similar HOMO energy levels at -5.27 to $\sim-5.38 \mathrm{eV}$. The deep HOMO energy level could offer these polymers good chemical stability and high $V_{\text {oc }}$. The LUMO values for P1-P4 are $-2.97,-3.39,-2.91$ and $-2.84 \mathrm{eV}$, respectively. As expected, the introduction of electron-withdrawing cyanovinylene bridge into the pendant group of P1 lowered the LUMO level from 

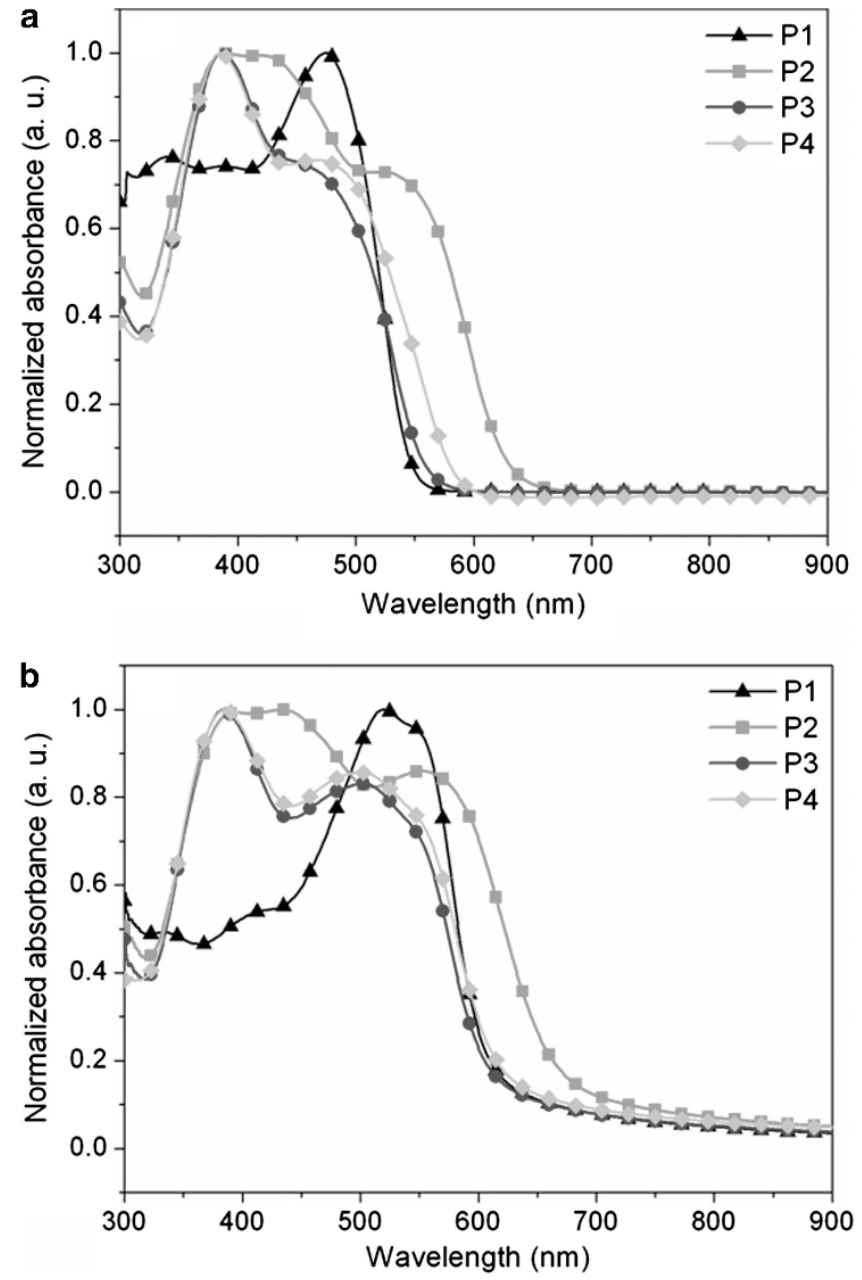

Figure 3 UV-vis absorption spectra of polymers P1-P4: (a) $\mathrm{CHCl}_{3}$ solution; (b) film. A full color version of this figure is available at Polymer Journal online.

Table 1 Optical and electrochemical properties for polymers P1-P4

\begin{tabular}{|c|c|c|c|c|c|c|c|c|c|}
\hline \multirow[b]{2}{*}{ Polymers } & \multicolumn{2}{|c|}{$\lambda_{\max }(n m)$} & \multirow{2}{*}{$\begin{array}{c}\lambda_{\text {onset }} \\
(\mathrm{nm}) \\
\text { Film }\end{array}$} & \multirow{2}{*}{$\begin{array}{l}\mathrm{E}_{g}^{o p t} \\
(\mathrm{eV})^{\mathrm{a}}\end{array}$} & \multirow{2}{*}{$\begin{array}{l}E_{o x}^{o n} \\
(V)\end{array}$} & \multirow{2}{*}{$\begin{array}{l}\mathrm{E}_{\text {red }}^{o n} \\
(V)\end{array}$} & \multirow{2}{*}{$\begin{array}{c}\text { HOMO } \\
(\mathrm{eV})^{\mathrm{b}}\end{array}$} & \multirow{2}{*}{$\begin{array}{c}\text { LUMO } \\
(\mathrm{eV})^{\mathrm{b}}\end{array}$} & \multirow{2}{*}{$\begin{array}{l}\mathrm{E}_{g}^{e g} \\
(\mathrm{eV})\end{array}$} \\
\hline & Solution & Film & & & & & & & \\
\hline P1 & 474 & 520 & 604 & 2.05 & 0.52 & -1.83 & -5.32 & -2.97 & 2.35 \\
\hline P2 & 389 & 433 & 667 & 1.86 & 0.57 & -1.41 & -5.37 & -3.39 & 1.98 \\
\hline P3 & 386 & 383 & 608 & 2.04 & 0.58 & -1.89 & -5.38 & -2.91 & 2.47 \\
\hline P4 & 385 & 384 & 617 & 2.01 & 0.47 & -1.96 & -5.27 & -2.84 & 2.4 \\
\hline
\end{tabular}

aCalculated according to the onset wavelength of film absorption, $E_{\mathrm{g}}^{\mathrm{opt}}=1240 / \lambda_{\text {onset }}$

${ }^{\mathrm{b}}$ Calculated according to equations: $E_{\mathrm{HOMO}}=-\mathrm{e}\left(E_{\mathrm{OX}}^{\mathrm{OO}}+4.8\right)(\mathrm{eV}) ; E_{\mathrm{LUMO}}=-\mathrm{e}\left(E_{\mathrm{red}}^{\mathrm{On}}+4.8\right)(\mathrm{eV})$ $E_{\mathrm{g}}^{\mathrm{ec}}=E_{\mathrm{LUMO}}-E_{\text {HOMO }}(\mathrm{eV})$.

$-2.97 \mathrm{eV}$ of $\mathbf{P} \mathbf{1}$ to $-3.39 \mathrm{eV}$ of $\mathbf{P} 2$. For $\mathbf{P} \mathbf{3}$ and $\mathbf{P} 4$, with an additional phenylene bridge, there is almost no change in LUMO, suggesting that phenylene bridge might destroy the coplanarity of the conjugated side chain and block the electron-withdrawing effect of cyanovinylene moiety. $\mathbf{P} 2$ has the smallest bandgap of $1.98 \mathrm{eV}$, which is favorable for absorbing more sunlight.

Solar cells with a configuration of ITO/PEDOT:PSS/Polymer: $\mathrm{PC}_{61} \mathrm{BM} / \mathrm{Ca} / \mathrm{Al}$ were fabricated. Polymer: $\mathrm{PC}_{61} \mathrm{BM}$ ratios $(\mathrm{w} / \mathrm{w})$ for P1-P4 devices were optimized from 1:0.5 to 1:3. Performance
Table 2 Performance for solar cells based on P1-P4/PC ${ }_{61} \mathrm{BM}$ blends

\begin{tabular}{lccccc} 
Polymers & Polymer/PC 61 BM (W/W) & $\mathrm{V}_{o c}(\mathrm{~V})$ & $\mathrm{J}_{s c}\left(\mathrm{mAcm}^{-2}\right)$ & $F F(\%)$ & $P C E(\%)$ \\
\hline P1 & $1: 1$ & 0.92 & 1.71 & 49 & 0.90 \\
P2 & $1: 2.5$ & 0.93 & 3.51 & 49 & 1.89 \\
P3 & $1: 1$ & 0.93 & 1.98 & 44 & 0.95 \\
P4 & $1: 1.5$ & 0.93 & 2.64 & 50 & 1.45 \\
\hline
\end{tabular}

parameters for P1-P4 solar cells are listed in Table 2 and $J-V$ curves are shown in Supplementary Figure S3. As expected, all solar cells show high $V_{\text {oc }}(0.92 \sim 0.93 \mathrm{~V})$, resulting from the low HOMO levels of P1-P4. P2 cells exhibit the highest PCE of 1.89\% with a $J_{\mathrm{sc}}$ of $3.51 \mathrm{mAcm}^{-2}$ and a FF of $49 \%$. The better photovoltaic performance of $\mathbf{P} 2$ results from its higher $J_{\mathrm{sc}}$, originating from better absorption of $\mathbf{P} \mathbf{2}$ and the stronger ICT between the backbone donor and the pendant acceptor. The optimized thicknesses for P1-P4/PC ${ }_{61}$ BM active layers are 103, 115, 98 and $105 \mathrm{~nm}$, respectively. Solvent annealing did not help to improve solar cell performance in this work.

\section{SUMMARY}

We have designed and synthesized a series of two-dimensional conjugated polymers (P1-P4) based on a backbone consisting of a BDT donor unit and a thiophene unit, which was grafted with different acceptor groups. These polymers show good solubility, thermal stability, and tunable optical and electrochemical properties. Bulk heterojunction polymer solar cells based on P2 exhibit a PCE of $1.89 \%$ and an impressively high $V_{\text {oc }}$ of $0.93 \mathrm{~V}$. Further efforts to lower the bandgaps of these polymers with the aim to enhance photocurrent are currently ongoing.

\section{ACKNOWLEDGEMENTS}

This work was supported by the ' 100 Talents Program' of Chinese Academy of Sciences and Jiahong Optoelectronics.

1 Yu, G., Gao, J., Hummelen, J. C. \& Heeger, A. J. Polymer photovoltaic cells: enhanced efficiencies via a network of internal donor-acceptor heterojunctions. Science $\mathbf{2 7 0}$ 1789-1791 (1995).

2 Günes, S., Neugebauer, H. \& Sariciftci, N. S. Conjugated polymer-based organic solar cells. Chem. Rev. 107, 1324-1338 (2007).

3 Shen, X. X., Chen, S., Xiao, Z., Zuo, Q. Q., Chen, Y. W. \& Ding, L. Synthesis of thienoselenadiazole-containing conjugated copolymers and their application in polymer solar cells. Polym. J. 44, 978-981 (2012).

4 Hong, Y. R., Wong, H. K., Moh, L. C. H., Tan, H. S. \& Chen, Z. K. Polymer solar cells based on copolymers of dithieno[3,2-b:2', $3^{\prime}$-d]silole and thienopyrroledione. Chem. Commun. 47, 4920-4922 (2011).

5 Wu, P. T., Bull, T., Kim, F. S., Luscombe, C. K. \& Jenekhe, S. A. Organometallic donoracceptor conjugated polymer semiconductors: tunable optical, electrochemical, charge transport, and photovoltaic properties. Macromolecules 42, 671-681 (2009).

6 Susarova, D. K., Khakina, E. A., Troshin, P. A., Goryachev, A. E., Sariciftci, N. S., Razumov, V. F. \& Egbe, D. A. M. Photovoltaic performance of PPE-PPV copolymers: effect of the fullerene component. J. Mater. Chem. 21, 2356-2361 (2011).

7 Zhang, C. Y., Chen, S., Xiao, Z., Zuo, Q. Q. \& Ding, L. Synthesis of mono- and bisadducts of thieno-o-quinodimethane with $\mathrm{C}_{60}$ for efficient polymer solar cells. Org. Lett. 14, 1508-1511 (2012).

8 Park, S. H., Roy, A., Beaupre, S., Cho, S., Coates, N., Moon, J. S., Moses, D., Leclerc, M., Lee, K. \& Heeger, A. J. Bulk heterojunction solar cells with internal quantum efficiency approaching 100\%. Nat. Photonics 3, 297-303 (2009).

9 Cao, J. M., Zhang, W., Xiao, Z., Liao, L. Y., Zhu, W. G., Zuo, Q. Q. \& Ding, L. Synthesis and photovoltaic properties of low band gap polymers containing benzo[1,2-b:4,5 c']dithiophene-4,8-dione. Macromolecules 45, 1710-1714 (2012).

10 Huang, F., Chen, K. S., Yip, H. L., Hau, S. K., Acton, O., Zhang, Y., Luo, J. D. \& Jen, A. K. Y. Development of new conjugated polymers with donor- $\pi$-bridge-acceptor side chains for high performance solar cells. J. Am. Chem. Soc. 131, 13886-13887 (2009). 
11 Gu, Z. J., Shen, P., Tsang, S. W., Tao, Y., Zhao, B., Tang, P., Nie, Y. J., Fang, Y. \& Tan, S. T. Development of a new benzo[1,2-b:4,5-b']dithiophene-based copolymer with conjugated dithienylbenzothiadiazole-vinylene side chains for efficient solar cells. Chem. Commun. 47, 9381-9383 (2011).

12 Tsai, J. H., Lee, W. Y., Chen, W. C., Yu, C. Y., Hwang, G. W. \& Ting, C. New twodimensional thiophene-acceptor conjugated copolymers for field effect transistor and photovoltaic cell applications. Chem. Mater. 22, 3290-3299 (2010).

13 Hou, J. H., Huo, L. J., He, C., Yang, C. H. \& Li, Y. F. Synthesis and absorption spectra of poly(3-(phenylenevinyl)thiophene)s with conjugated side chains. Macromolecules 39, 594-603 (2006).

14 Zhang, Z. G., Liu, Y. L., Yang, Y., Hou, K. Y., Peng, B., Zhao, G. J., Zhang, M. J., Guo, X., Kang, E. T. \& Li, Y. F. Alternating copolymers of carbazole and triphenylamine with conjugated side chain attaching acceptor groups: synthesis and photovoltaic application. Macromolecules 43, 9376-9383 (2010).

15 Mikroyannidis, J. A., Kabanakis, A. N., Balraju, P. \& Sharma, G. D. Enhanced performance of bulk heterojunction solar cells using novel alternating phenylenevinylene copolymers of low band gap with cyanovinylene 4-nitrophenyls. Macromolecules 43, 5544-5553 (2010).

16 Liang, Y. Y., Feng, D. Q., Wu, Y., Tsai, S. T., Li, G., Ray, C. \& Yu, L. P. Highly efficient solar cell polymers developed via fine-tuning of structural and electronic properties. J. Am. Chem. Soc. 131, 7792-7799 (2009).

17 Hou, J. H., Chen, H. Y., Zhang, S. Q., Chen, R. I., Yang, Y., Wu, Y. \& Li, G. Synthesis of a low band gap polymer and its application in highly efficient polymer solar cells. J. Am. Chem. Soc. 131, 15586-15587 (2009).

18 Zhang, G. B., Fu, Y. Y., Zhang, Q. \& Xie, Z. Y. Benzo[1,2-b:4,5-b']dithiophenedioxopyrrolothiophen copolymers for high performance solar cells. Chem. Commun. 46, 4997-4999 (2010).

19 Hou, J. H., Park, M. H., Zhang, S. Q., Yao, Y., Chen, L. M., Li, J. H. \& Yang, Y. Bandgap and molecular energy level control of conjugated polymer photovoltaic materials based on benzo[1,2-b:4,5-b']dithiophene. Macromolecules 41, 6012-6018 (2008).

20 Fernandes, J. A., Morisaki, Y. \& Chujo, Y. Aromatic-ring-layered polymers composed of fluorene and xanthenes. Polym. J. 43, 733-737 (2011).

Supplementary Information accompanies the paper on Polymer Journal website (http://www.nature.com/pj) 